\title{
Potency of aloe extract as immunostimulant for carp (Cyprinus carpio) against Aeromonas salmonicida
}

\author{
SRI ANDAYANI ${ }^{1, \boldsymbol{v}}$, M. SULAIMAN DADIONO ${ }^{2}$, WIDYA TRI ELWIRA ${ }^{1}$, FEBBY HADI SETYAWAN ${ }^{1}$ \\ ${ }^{1}$ Department of Aquaculture, Faculty of Fisheries and Marine Science, Universitas Brawijaya, Jl. Veteran, Malang 65149, East Java, Indonesia \\ Tel.: +62-341-553512, Fax.: +62-341-556837, `email: yanik@ub.ac.id; srianday_08@yahoo.com \\ ${ }^{2}$ Faculty of Fisheries and Marine Science, Universitas Jenderal Soedirman. Jl. Dr. Soeparno, Purwokerto Utara, Banyumas 53122, Central Java, \\ Indonesia
}

Manuscript received: 27 November 2019. Revision accepted: 2 January 2020.

\begin{abstract}
Andayani S, Dadiono MS, Elwira WT, Setyawan FH. 2020. Potency of aloe extract as immunostimulant for carp (Cyprinus carpio) against Aeromonas salmonicida. Biodiversitas 21: 860-864. The objective of the study was to be able to know the cellular and humoral non-specific immune response to Aeromonas salmonicida after aloe extract administration. This study employed Complete Randomized Design with 3 treatments and 3 replications, control treatment $(\mathrm{K}), \mathrm{A}=2 \mathrm{ppm}$ of aloe extract application in the media, $\mathrm{B}=$ $16 \mathrm{ppm}$ of aloe extract in the media, and $\mathrm{C}=30 \mathrm{ppm}$ of aloe extract in the media. The extract was given through one-hour soaking at day 0 and day 7 , and then challenge-tested to $10^{7}$ cells. $\mathrm{ml}^{-1}$ of $A$. salmonicida into the media for one day. Results showed that administration of aloe extract could raise plasma protein levels from 443.0 to $662.0 \mathrm{mg} . \mathrm{Kg}^{-1}$ antibody from 1.2576 to 3.3974 , and phagocytic activity from $30.61 \%$ to $45.94 \%$. Similarly, the differential value of leucocyte (lymphocyte from 58.6\% to $73.70 \%$, neutrophils from 6.09 to $8 \%$, and monocyte from $5.70 \%$ to $7.72 \%$ ). As conclusion, aloe extract at the dose of 2 ppm could raise the cellular and humoral non-specific immune. Therefore, the use of aloe extract as immunostimulant at the dose of $2 \mathrm{ppm}$ applied through immersion could also apply other methods, such as oral and injection.
\end{abstract}

Keywords: Aloe extract, carp, cellular non-specific immune response, humoral

\section{INTRODUCTION}

Carp Cyprinus carpio culture intensification has caused a number of disease outbreaks with increase in causing pathogens. Aeromonas salmonicida is one of the most serious problems in various stages of carp culture that can result in mortality of fish fry or fingerling up to $99 \%$ from pathogenic bacterial infection (Harikrishnan et al. 2011).

The outbreak level of $A$. salmonicida in carp hatchery can be known in several hours. According to Idowu et al. (2017), A. salmonicida can singly infect fish and multiply very fast so that it can kill fish in few days.

Infection of $A$. salmonicida can make damages to fish organs and skin wounds (Moriarty 1997). To control the disease, particularly from bacteria, various types of antibiotics, such as chloramphenicol, oxytetracycline, and erythromycin have been used (Kerry et al. 1997; Hameed et al. 2003), but these utilizations are reported to result in resistance of the new strains (Harikrishnan et al. 2010; Hameed et al. 2003). Therefore, the use of natural substances, that are still limited to saponin and rotenone, needs new breakthrough by benefiting aloe plant Aloe vera as an environmental friendly immunostimulant (Harikrishnan et al. 2010; Sakai 1999; Andayani 2007). This plant, according to Sahu et al. (2013), contains amino acid, enzyme, hormone, mineral, saponin, flavonoid, polyphenol, and tannin. Quispe et al. (2018) added that compounds of the aloe plant consist of phenols in the form aloe-emodin, isoquercitrin, and chrysophanol. The administration of aloe plant as immunostimulant given through soaking can be done on $15 \mathrm{~g}$-fish fries. Injection is less efficient for fish fry and the fish safety cannot be guaranteed.

Hence, a study is needed to explore the natural resources in order to obtain benefit of bioactive compounds of the aloe plant as immunostimulant for immune response development, especially the carp baby fish, to increase survivorship and prevent the fish infection in the carp culture activities. Nevertheless, the use of the immunostimulant advantages of aloe bioactive compounds has been able to utilize and extensively apply in fish culture, so that more serious and detail examination can be very interesting and absolute to do. This study is directed to know the cellular and humoral non-specific immune response to the administration of aloe extract against $A$. salmonicida.

\section{MATERIALS AND METHODS}

\section{Materials}

The experimental fish were carp $C$. carpio of one hatching taken from Aquaculture Center of Blitar that were reared at the density of 10 ind. $15 \mathrm{~L}^{-1}$, with mean total length of $\pm 8 \mathrm{~cm}$. Acclimation was done for 2 weeks, and water replacement was conducted as much as $10-20 \%$ of total volume once a week 


\section{Food material}

The fish were fed with fresh chopped bonito and sardines. Feeding was done ad libitum twice a day at 07.00 am and $16.00 \mathrm{pm}$.

\section{Aloe extraction method}

Aloe plant extract was obtained from Material Medica, Batu, East Java, Indonesia. Extraction followed Setyaningsih et al. (2017), in which it was accomplished through maceration and evaporation. It employed three different solvents, ethanol, ethyl acetate, and n-hexane. The use of these three solvents was intended to examine the phytochemical content in the aloe powder. The plant was macerated in the solvent as 1:4 for 3 days and stirred each $24 \mathrm{~h}$ (Prahesti et al. 2015). Afterward, filtration was conducted using filter cloth up to no deposit was left, then dried in a rotary vacuum evaporator at $45^{\circ} \mathrm{C}$ up to pasta was formed.

\section{Carp blood sampling}

The fish blood was collected twice, before infected or after immunostimulant administration for 7 days and one day after infected with bacteria $A$. salmonicida. Approximately $0.05 \mathrm{ml}$ of blood was collected from caudal vein of 10 fish at 7 and 1 days post-infection and were allowed to coagulate overnight at $4^{\circ} \mathrm{C}$. EDTA and an aqueous solution of $\mathrm{Na}$-citrate were used as anticoagulants. Serum was obtained by centrifugation at $8000 \mathrm{rpm}$ for 10 min (Harikrishnan et al. 2003; Kordon et al. 2018). The parameters measured were differential leucocytes following Biyanti (2005), the phagocytic activity isolation based on Irianto and Budiono (2004), and plasma protein and titer antibody using Harikrishnan et al. (2010).

\section{Experiment}

The study employed Complete Randomized Design with 3 treatments and one negative control and one positive control, each of which had 3 replications as follows:

A : treatment of $2 \mathrm{ppm}$ aloe extract administration.

B : treatment of $16 \mathrm{ppm}$ aloe extract administration.

$\mathrm{C}$ : treatment of $30 \mathrm{ppm}$ aloe extract administration.

$\mathrm{K}$ : treatment of $0 \mathrm{ppm}$

$1,2,3$ : treatment replication.

The aloe extract was administered in day- 1 and boostered in day-7, with one-hour soaking. The aloe extract was given through soaking in 3 different treatment concentrations. Each tank contained $15 \mathrm{~L}$ of water according to the treatment doses, then 10 individuals of fish were soaked into each treatment tank. Bacterial $A$. salmonicida infection was carried out after 7 days of the aloe extract soaking. Bacterial density was set $10^{7}$ cells.mL ${ }^{1}$ for $24 \mathrm{~h}$ (Andayani 2006). Water quality parameters, such as $\mathrm{pH}$, temperature, and DO, measurements were also accomplished. Parameter observations included cellular non-specific immune, such as differential leucocyte, and phagocytic activity, and humoral non-specific immunes, such as titer antibody and plasma proteins. Immune data collection was done before infection, after aloe extract administration (day-7), and after infected with $A$. salmonicida (day-9).
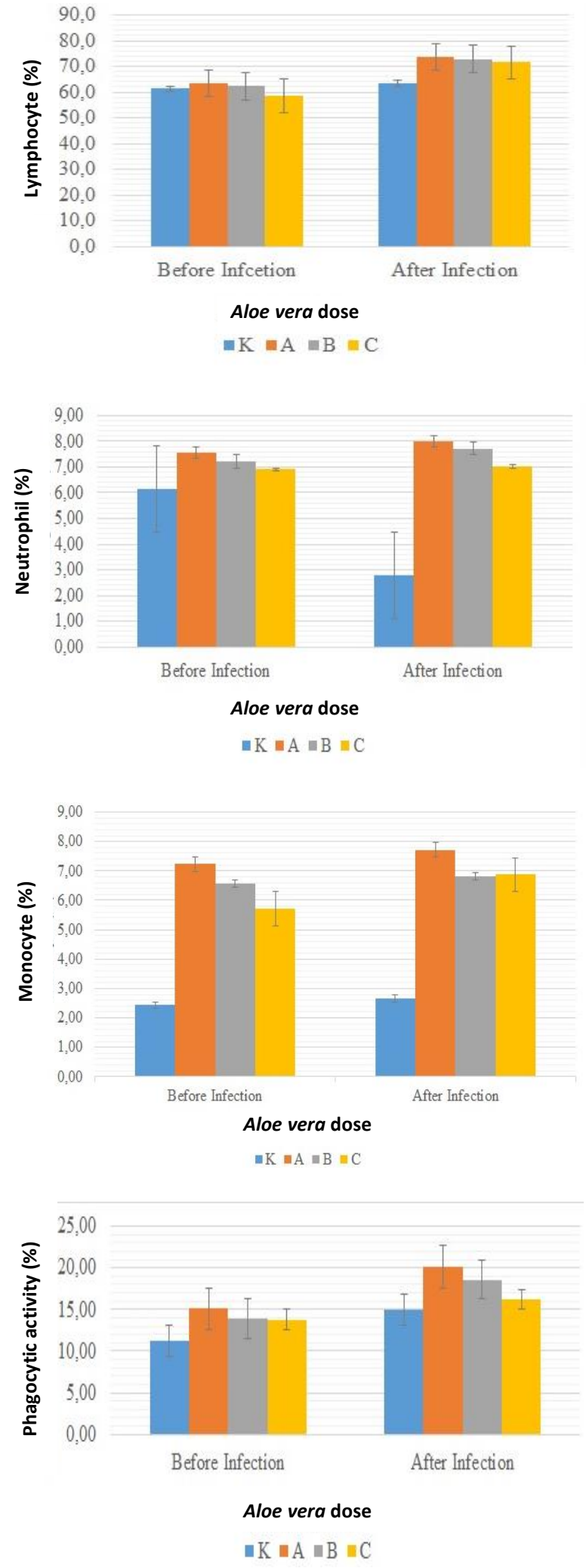

Figure 1. Relationship of Aloe vera dose with lymphocyte (\%), neutrophil (\%), monocyte (\%), and phagocytotic activity $(\%)$ 


\section{RESULTS AND DISCUSSION}

\section{Cellular non-specific immune}

The relationship between the aloe extract dose and the cellular non-specific immune parameter before infection (after aloe extract immunostimulant administration) up to infection period of the carp is demonstrated in Figure 1.

\section{Humoral non-specific immune}

The relationship between the aloe extract dose and the humoral non-specific immune parameter before infection (after aloe immunostimulant administration) up to the carp infection period is presented in Figure 2.

\section{Discussion}

The differential lymphocytes ranged from 58.6 to $73.70 \%$. This range occurs in the standard range of $60-80 \%$ lymphocytes (Uribe et al. 2011). Our observations showed that number of lymphocytes increased from that before infection (after aloe extract administration) up to infection period. Treatment $\mathrm{C}(30 \mathrm{ppm})$ gave lower number of lymphocytes than B (16 ppm) and A (2 ppm) since the active compound of phenolic content in the aloe was too saturated so that it is toxic for the fish. These findings are supported by the results of previous investigations (Solatanian and Fereidoni 2016). Due to high doses, it can cause physiological disorders in the form of stress (Harikrishnan et al. 2010). Stress could cause problem in the non-specific immune response, such as lymphocyte proliferation (increase in number of cells and structural change to $\mathrm{T}$ cells and $\mathrm{B}$ cells). Stress also pushes the release of cortisol hormone that could press the immune system after stimulated and could make depression of lymphocyte, macrophage, and leucocyte (Galindo 2004; Uribe et al. 2011). As a result, it could result in physiological disturbance in the form of stress (Harikrishnan et al. 2010).

Neutrophil standard ranges from 6 to $8 \%$ (Anderson 1974). The present study indicates that all the extracts and doses could increase the number of neutrophils from the first day to the infection period of 7.57 to $8 \%$. Number of neutrophils increased with dose of aloe extract administration as response to increased bacterial invasion. Neutrophils reflect phagocytotic activity that is able to attack and kill the bacteria, viruses, and other deleterious or hazardous agents attacking the body. Its major role is as early defense of non-specific immune to bacterial infection (Vadstein 1997). Activated neutrophils ingest pathogens and produce reactive oxygen species, release toxic substances from intracellular granules, thus becoming very potent killers (Kordon et al. 2018).

Number of monocytes ranged from 5.70 to $7.72 \%$ before and after A. salmonicida infection. Based on the present study, the number of monocytes increased from the first day to the infection period. The best treatment was found at the dose of $2 \mathrm{ppm}$, followed by $16 \mathrm{ppm}$, and then 30 ppm (Figure 1). Giving high doses of immunosuppressive, which can suppress immune action. These findings are also supported by Sakai (1999) that cytotoxic compounds such as phenols can have immunosuppressive effects at high doses. Immunosuppressive can inhibit the proliferation of immune cells and $\mathrm{T}$ cell lymphokine production. Dügenci et al. (2003), support the immunosuppressive substances can affect the phagocytic system by suppressing the myelopoiesis system will reduce the formation of oxidants or bind oxidants. Emphasis on the myelopoiesis system will reduce the number of differential leukocytes (monocytes). Suppression of the myelopoiesis system can be caused by toxic effects of immunosuppressive compounds. Increase in percent monocyte during infection of the bacteria $A$. salmonicida could result from monocytes of the fish body that destroy the antigen (A. salmonicida). The monocyte proportion is very low in the leucocyte, but it can increase about $38 \%$ in a short time if infection occurs. Monocyte is believed to function as macrophage and destroy the antigen entering the body. The monocyte's phagocytosis is similar process to the neutrophil, and this monocyte can possess durable phagocytotic activity (Abbas and Lichman 2005; Scombes and Wang 2012; Kordon et al. 2018).



Figure 2. The relationship of Aloe vera dose with plasm protein content and titer antibody 
The phagocytic activity (Figure 1) caused by the macrophage not only occurs through direct interaction with the invading antigen like microorganisms, but could also be activated by lymphocyte product (lymphokine) stimulated by the antigen of the phenolic compounds. Cytokines are important mediator proteins in the immune system. Cytokines can be produced by lymphocytes (lymphokines), or monocytes (monokines) with pro-inflammatory and antiinflammatory effects. The equilibrium between proinflammatory cytokines and anti-inflammatory cytokines is considered an important parameter in the homeostasis of immune and inflammatory responses in disease attacks (Boshtam et al. 2017). In vivo and in vitro studies show that polyphenols affect macrophages by inhibiting several major regulators of the inflammatory response (Gonzales et al. 2011). Once the macrophagic cell is activated, it will show the metabolic activity and the function development to phagocytize and kill the antigen and process it (Abbas and Lichtman 2005). Phagocytosis is followed by metabolism development as "Respiratory burst" (Anderson and Siwicki 1995; Galindo 2004). Phagocytosis starts from contact between cell membranes and toxins. This will activate the flavoenzymatic system on the NADP (Nicotinamide Adenine Dinucleotide Phosphate) oxidase membrane, so that Reactive Oxygen Intermediates (ROI) is formed and yields superoxide anion $\left(\mathrm{O}_{2}^{-}\right)$. Superoxide dismutase is an enzyme that alternately catalyzes the dismutation of the superoxide radical into either ordinary molecular oxygen or hydrogen peroxide and forms radical hydroxyl $\left(\mathrm{OH}^{-}\right)$. Superoxide dismutase is an enzyme that alternately catalyzes the dismutation of the superoxide $\left(\mathrm{O}_{2}^{-}\right)$radical into two less damaging species: either molecular oxygen $\left(\mathrm{O}_{2}\right)$ or hydrogen peroxide $\left(\mathrm{H}_{2} \mathrm{O}_{2}\right)$. Superoxide is produced as a by-product of oxygen metabolism and, if not regulated, causes numerous types of cell damage. SOD is an important antioxidant defense in nearly all living cells exposed to oxygen (Ardó et al. 2010; Fukai and Ushio-Fukai 2011; Desai and Bhilave 2018). The ability of phagocytosis to kill microbial pathogens is a very important process in the mechanism of disease prevention. The phagocytic activity in the present study before infection or after immunostimulant administration and after infection increased from $36.61 \%$ to $45.94 \%$. Castro et al. (2004) also found that the administration of seaweed extracts, such as Ulva rigida, Enteromorpha sp, and Codium tomentosa, through one-hour soaking raised the phagocytosis from $34 \%$ to $60 \%$.

The increased phagocytosis is followed by increase in protein content of the blood plasma at the control treatment up to the immunostimulant administration or before infection, from 442.67 to $661.0 \mathrm{mg} \cdot \mathrm{Kg}^{-1}$. Because aloe extract contains a protein that can increase blood plasma in the body of the fish (Harikrishnan et al. 2009; Kiron 2012). It is consistent with Magnadottir (2006) that blood plasma is basically liquid solution containing $80-90 \%$ protein, such as albumin, immunoglobin (antibody), and various enzymes and other components, such as blood-freezing agent, hormone, and various types of salts. Then, after being infected plasma protein decreases from 661.0 to $506.00 \mathrm{mg} \cdot \mathrm{kg}^{-1}$. Decrease in protein content causes the fish to use protein to fight bacterial infections A. salmonicida in the form of hemorrhagic, necrosis, of the liver, lymph, kidney, and other tissues. These findings are supported by (Irianto 2005; Marentek et al. 2013), a bacteria can cause damage to blood cells, it can even cause the cessation of host cell macromolecular synthesis to prevent the synthesis of proteins and nucleic acids.

One of the protein functions, according to Anderson (1974), is to maintain the carp to fight against various bacterial infections. Protein in the blood plasma will push the fishspecific and non-specific immune. The increase in plasma protein level could be affected by several factors, but according to Scombes and Wang (2012) and Sakai (1999), the main one is compound concentration. Harikrishnan et al. (2010) also claimed that tremendously high dose administered could not raise the immune, since the fish body is not capable of responding to the cellular and humoral response working mechanism, so that the antibody is not formed.

The presence of antigen or immunogen in the test fish body will stimulate the formation of specific and nonspecific immune responses. The antigen of the present study is phenolic compound of the aloe extract and the bacterium $A$. salmonicida. In this case, B cells work in the immune system that will eventually develop to be plasma cells. Plasma cells have cytoplasm with very basophilic properties and are rich in ribosomes that produce the antibody (Magnadottir 2006). The plasma cells are capable of producing as many as 300 antibody molecules every second and sometimes the antibody molecules gather in the cell before release.

Besides plasma protein in the blood plasma, there is also antibody. The highest titer antibody was recorded in treatment A (2 ppm). Fish exposed to the antigen ( $A$. salmonisida) will create antibody. According to Abbas and Lichman 2005), if serum contains an antibody, when the serum is exposed to antigen, complex agglutination will occur between the antigen and the antibody, and immersion treatment is very effective to the antibody because the aloe extract as immunostimulant passes the gill, skin, and the lateral line.

The extent of the antibody is affected by the ability of the macrophage to give the response to the lymphocytes to produce specific antibody with the entering antigens (Harikrishnan et al. 2011). High number of titer antibody is influenced by optimal dose administration. The antigen entering the fish body will be firstly responded by APC cells (antigen-presenting cells) that consist of macrophages, lymphocyte B, and dendritic cells. Then, the macrophages will break the antigen into smaller fragments (epitope) and presented to $\mathrm{T}$ cells through class II-major histocompatibility complex (MHC). Afterward, the T cells will catch the antigen through TCR ( $T$-cell receptor), and the activated T cells will secrete cytokine, such as IL-2, IL4, IL-6, dan IL-10 (Scombes and Wang 2012; Sari et al. 2013; Uribe et al. 2011).

Aloe extract containing phenolic compounds could raise the protein level of the blood plasma, the titer antibody after aloe extract administration and infected with bacteria, increase the phagocytic activity from $30.61 \%$ to 
$45.94 \%$, the differential leucocytes (lymphocyte from $58.6 \%$ to $73.70 \%$, neutrophils from 6.09 to $8 \%$, and monocyte from $5.70 \%$ to $7.72 \%$ ). Therefore, the aloe extract of $2 \mathrm{ppm}$ could enlarge the cellular and humoral non-specific immune and could be used as immunostimulant through immersion. Other methods of administration could be tried as well, such as oral supply and injection.

\section{ACKNOWLEDGEMENTS}

This study is funded by Professor's Research Grant of Brawijaya University, Malang, Indonesia. The authors would also appreciate Muhammad Eka Supriya Danny and Titin Yuniastutik who gave technical assistance during the study at the Faculty of Fisheries and Marine Science, Brawijaya University, Malang, East Java, Indonesia.

\section{REFERENCES}

Abbas A, Lichman A. 2005. Cellular and molecular immunology. DNA Illutrations Inc, Philadelphia.

Andayani S. 2007. The Effect of Alkaloid Bioactive of Jellyfish (Bougaivilia sp) as Immunostimulant on the Bactericide Activity, Non-Specific Immune Response and Relative Percent Survival of Tiger grouper (Epinephelus fuscoguttatus). [Dissertation]. Brawijaya University, Malang. [Indonesian]

Anderson DP, Siwicki AK. 1995. Basic hematology and serology for fish health programs. In: Syarif M, Arthur JR, Subasinghe JP (eds.). Diseases in Asia Aquaculture II. Fish Health Section, Asian Fisheries Society Publisher, Manila, Philippines.

Anderson DP. 1974. Fish immunology. In: Snieszko SF, Axelrod HR (eds). Diseases of Fishes. T.F.H. Publications Inc. Ltd. U.S.A.

Ardó L, Jeney Z, Adams A, Jeney G. 2010. Immune responses of resistant and sensitive common carp families following experimental challenge with Aeromonas hydrophilla. Fish Shellfish Immunol 29: 111-116.

Biyanti R. 2005. Fish hematology: Technique of fish blood sampling and hematological examination. Bagian Ilmu Kedokteran Dasar Veteriner Fakultas Kedokteran Hewan Universitas Airlangga, Surabaya. [Indonesian]

Boshtam M, Asgary S, Kouhpayeh S, Shariati L, Khanahmad H. 2016 Aptamers against pro- and anti-inflammatory cytokines: a review. Inflammation 40 (1): 340-349.

Castro R, Zarra I, Lamas J. 2004. Water-soluble seaweed extract modulates the respiratory burst activity of turbot phagocytes. J Aquacult 229: 67-78.

Desai TH, Bhilave MP. 2018. Toxicological studies of methanol on superoxide dismutase (SOD) activity of freshwater fish Cirrhinus mrigala. Intl J Fish Aquat Stud 6 (5): 20-22.

Dügenci SK, Arda N, Candan A. 2003. Some medicinal plants as immunostimulant for fish. J Ethnopharmacol 88: 99-106.

Fukai T, Ushio-Fukai M. 2011. Superoxide dismutases: role in redox signaling, vascular function, and disease. Antioxid Redox Signaling 15 (6): 1583-1606.

Galindo VJ, Hosokawa H. 2004. Immunostimulants: Toward temporary prevention of diseases in marine fish. Kochi University, Kochi, Japan

González R, Ballester I, Posadas RL, Suárez MD, Zarzuelo A, Augustin OM, Medina FSD. 2011. Effects of flavonoids and other polyphenols on inflammation. Crit Rev Food Sci Nutr 51 (4): 331-362.

Hameed AS, Rahaman KH, Alagan A, Yoganandhan K. 2003. Antibiotic resistance in bacteria isolated from hatchery-reared larvae and postlarvae of Macrobrachium rosenbergii. J Aquac 217: 39-48.

Harikrishnan R, Balasundaram C, Heo MS. 2010. Molecular studies, disease status, and prophylactic measures in grouper aquaculture: economic importance, diseases, and immunology. J Aquacult 30: 114.

Harikrishnan R, Balasundaram C, Heo MS. 2011. Diet enriched with mushrooms Phellinus linteus extract enhances the growth, innate immune response, and disease resistance of kelp grouper, Epinephelus bruneus against vibriosis. J Fish Shellfish Immunol 30: 128-134.

Harikrishnan R, Balasundaram C, Kim MC, Kim JS, Han YJ, Heo MS. 2009. Innate immune response and disease resistance in Carassius auratus by triherbal solvent extracts. J Fish Shellfish Immunol 27: 508-515.

Harikrishnan R, Balasundaram C, Heo MS. 2010. Herbal supplementation diets on hematology and innate immunity in goldfish against Aeromonas hydrophilla. J Fish Shellfish Immunol 28: 354-361.

Idowu TA, Adedeji HA, Sogbesan OA. 2017. Fish diseases and health management in aquaculture production. Intl J Environ Agric Sci 1: 16.

Irianto A. 2005. Patologi Ikan Teleostei. Universitas Gajah Mada, Yogyakarta. [Indonesian]

Irianto H, Budiono. 2004. The effect of probiotic A3-51 supplementation in feed on the macrophage of carp (Cyprinus carpio) kidney. Proceeding of National Seminary of Fish and Shrimp Disease IV, Purwokerto. [Indonesian]

Kerry J, NicGabhainn S, Smith P. 1997. Changes in oxytetracycline resistance of intestinal microflora following oral administration of this agent to Atlantic Salmon (Salmo salar L) smolt in a marine environment. J Aquacult 157: 187-195.

Kiron V. 2012. Fish immune system and its nutritional modulation for preventive health care. J Anim Feed Sci Technol 173: 111-133.

Kordon AO, Kars A, Pinchuk L. 2018. Innate immune responses in fish: Antigen-presenting cells and professional phagocyte. Turk J Fish Aquat Sci 18: 1123-1139

Kordon, AO, Abdelhamed H, Ahmed H, Park JY, Karsi A, Pinchuk LM. 2018. Phagocytic and bactericidal properties of channel catfish peritoneal macrophages exposed to Edwardsiella ictaluri live attenuated vaccine and wild-type strains. Front Microbiol 8: 1-11.

Magnadottir B. 2006. Innate immunity of fish. J Fish Shellfish Immunol 20: 137-151.

Marentek GA, Manoppo H, Longdong SNJ. 2013. Evaluation of the use of garlic (Allium sativum) in enhancing nonspecific immune response and growth of Nile Tilapia (Oreochromis niloticus). J Aquacult 1 (1): 1-7. [Indonesian]

Moriarty DJW. 1997. The role of microorganisms in aquaculture ponds. J Aquacult 151: 333-349.

Prahesti NR, Suzery M, Cahyono B. 2015. The antioxidant activities, phenolic total and cytotoxicity of extract and fractions of Aloe vera Linn. J Sci Math 23: 50-54. [Indonesian]

Quispe C, Villalobos M, Borquez J, Simmirgiotis M. 2018. Chemical composition and antioxidant activity of Aloe vera from the Pica Oasis (Tarrapaca, Chile) by UHPLC-Q/orbitrap/MS/MS. J Chem 1-12.

Sahu PK, Giri DD, Singh R, Pandey P, Gupta S, Shrivastava, Kumar A, Pandey KD. 2013. Therapeutic and medicinal uses of Aloe vera: A review. J Pharmacol Pharm 4: 599-610.

Sakai M. 1999. Current research status of fish immunostimulants. J Aquacult 172: 63-92.

Sari RH, Setyawan A, Suparmono. 2013. Increased inactive vaccine immunogenicity of Aeromonas salmonicida at addition of adjuvant to carp (Cyprinus carpio). e-J Aquac Eng Technol1: 87-94. [Indonesian]

Scombes CJ, Wang T. 2012. The innate and adaptive immune system of fish. Woodhead Publishing Limited, University of Aberdeen, UK.

Setyaningsih I, Hardjito L, Monintja DR, Sonduta MFA, Bintang M, Lailati N, Panggabean L. 2017. Extraction of antibacterial compounds from diatom Chaetoceros gracilis with various methods. J Indones Biol 5: 23-33. [Indonesian]

Soltanian S, Fereidouni MS. 2016. Effect of Henna (Lawsonia inermis) extracts on the immunity and survival of common carp, Cyprinus carpio infected with Aeromonas hydrophila. Intl Aquat Res 8 (3): 247-261.

Uribe C, Folch H, Enriquez R, Moran G. 2011. Innate and adaptive immunity in teleost fish: a review. Vet Med 56: 486-503.

Vadstein O. 1997. The use of immunostimulation in marine larviculture: possibiliti challenges. J Aquacult 155: 401-417. 